(RESEARCH ARTICLE)

\title{
Effect of medium size and compost dose on organic red lettuce (Lactuca sativa L. Var red rapids) cultivation in pots
}

\author{
Sugeng Triyono 1, ${ }^{*}$, Fadli Afrizki Surya Aditama 1, Elhamida Rezkia ${ }^{1}$, Dermiyati 2 and Jamalam Lumbanraja ${ }^{2}$ \\ 1 University of Lampung, College of Agriculture, Department of Agricultural Engineering, Sumantri Brojonegoro St \# 1, \\ Bandar Lampung City, Lampung Province, Indonesia, 35145. \\ 2 University of Lampung, College of Agriculture, Department of Soil Science, Sumantri Brojonegoro St \# 1, Bandar \\ Lampung City, Lampung Province, Indonesia, 35145.
}

Publication history: Received on 07 December 2020; revised on 14 December 2020; accepted on 16 December 2020

Article DOI: https://doi.org/10.30574/wjarr.2020.8.3.0476

\begin{abstract}
Small-scale urban farming business of organic vegetables was emerging in some locations of Indonesia. The study aimed to observe the effect of medium size and organic compost dosage on the growth and yield of red lettuce (Lactuca sativa L. var red rapids). A pot experiment was arranged in a completely randomized design (CRD) with a $3 \times 4$ factorial treatment using 3 replicates. Treatment consists of two factors namely medium size and organic compost dosage. The media size consisted of three levels: $1 \mathrm{~kg}$ (S1), $3 \mathrm{~kg}$ (S2), and $5 \mathrm{~kg}$ (S3). The dosage of organic compost consisted of 4 levels: $0 \%$ (D0), 10\% (D1), 30\% (D2), and 50\% (D3). The study was conducted in a plastic house, using a clay texture of subsoil and organic compost made from a mixture of cattle manure, chicken manure, MSG industrial waste sludge, coconut husk dust, oil palm empty fruit bunches (EFB). Some growth and yield parameters including water consumption and water productivity were considered. Results showed that red rapid lettuce growth was depressed at $1 \mathrm{~kg}$ and $3 \mathrm{~kg}$ medium sizes and growing more freely at $5 \mathrm{~kg}$ medium size. Three best yields of $75.3 \mathrm{~g}, 65.7 \mathrm{~g}$, and $90.0 \mathrm{~g}$ per plant were performed by the treatment combinations of $3 \mathrm{~kg}$ medium size- $10 \%$ compost dose, $3 \mathrm{~kg}$ medium size$30 \%$ compost dose, and 5kg medium size-50\% compost dose. The treatment combination of $3 \mathrm{~kg}$ medium size-10\% compost dose, however, could be considered as the most optimum treatment combination since it used the least amount of medium and compost although the plant experienced in restricted growth.
\end{abstract}

Keywords: Growth restriction; Medium size; Organic compost; Pot cultivation; Rapid red lettuce

\section{Introduction}

Organic farming has been increasingly receiving attention from consumers because organic foods are perceived as healthy foods [1] and free from the use of pesticides [2,3]. FAO data show a very significant increase in terms of organic farming area in the world during the last ten years. The organic farming area reached 13.02 million ha in 2008 and increased to 55.26 million ha in 2018 [4]. In organic cultivation, the use of unnatural materials or methods such as genetically modified organisms, conventional pesticides, synthetic fertilizers, antibiotics, or other substances are not permitted [5]. Organic produces are food products that are produced naturally and sustainably, do not threaten human health and degrade the environmental [6].

Organic farming on open farm areas encounters many challenges of contamination from the surrounding conventional farming systems. Irrigation water used by organic farmers could be easily contaminated with pesticides used by conventional farmers in the vicinity [7]. Pesticide droplets can be blown by the wind when neighboring farmers spray

\footnotetext{
${ }^{*}$ Corresponding author: Sugeng Triyono

University of Lampung, College of Agriculture, Department of Agricultural Engineering, Sumantri Brojonegoro St \# 1, Bandar Lampung City, Lampung Province, Indonesia, 35145. 
their crops [8]. Some windbreaks or buffer zones have been used to protect the organic crops from such contamination [9]. As such, the challenges of organic farming system development in conventional agricultural environments could be very complicated and costly to handle [10].

Greenhouse cultivations, especially in urban areas, could be a promising alternative to organic farming development. Greenhouse cultivations in urban areas have many advantages. The location of the cultivation is somewhat isolated so relatively protected from contamination, from the conventional agricultural environment [11]. Risks of contamination from the open agricultural farms could be diminished [12]. Groundwater or domestic water, which is cleaner than surface water or irrigation channels, can be made use for irrigation and more efficient if managed properly for smallscaled vegetable farming [13]. Because next to the housing the organic growers can utilize the state electricity to power the business rather than using self-generating electricity which is generally more expensive. Another advantage is that the organic vegetable farming systems are closer to the market so reducing transportation costs. Also, city people are generally aware of the need to consume healthy and safe foods, making marketing of organic vegetables much easier $[14,15,16]$.

However, developing a greenhouse vegetable farming system requires serious technical planning and financial calculations [17]. Inaccuracies in planning can cause growers to suffer economic losses. One of the important technical plans is to determine the planting medium volume and the dosage of organic fertilizers that will be used in the cultivation system, especially for in-pot cultivations. Growing vegetables in pots, polybags, or containers could be very efficient in irrigation and compost usages. In-pot cultivation, problems associated with soilborne diseases, nematodes or poor medium conditions can be easily managed $[17,18]$. But too small a volume of growing media could adversely affect vegetable growth, while too large pot size can potentially cause inefficiency and increase production costs [19].

Small-scaled urban farming business using a greenhouse (including a plastic or screenhouse) is emerging recently in the vicinity of some big cities of Indonesia. A household or small-scale business of organic vegetable farming in urban areas is an economic importance for many people of Indonesia. There is a mutual relationship between the growers and consumers. The growers gain daily income while consumers get healthy foods. One of the vegetables that is in great demand is lettuce because it can be consumed raw or as a salad mixture. Red lettuce (Lactuca sativa L. var Red rapids) is feasible to develop because red lettuce is known to contain many vitamins and minerals [20,21, 22], with an exceptional abundance of anthocyanins [23, 24, 25]. Anthocyanins, which are mostly found in vegetable epidermal cells, are known to be able to scavenge free radicals [26,27]. This type of red lettuce is also known as fast-growing and heat heat-tolerant [28], one important characteristic for tropical regions.

The research objective was to observe the effect of growth medium size and an organic compost dosage that had been developed previously and named as "Organonitrofos" [29, 30,31], on organic red lettuce productions. The optimum medium size and organic compost dose were determined as well.

\section{Material and methods}

The experiment was carried out in a screen-plastic house using subsoil media and "Organonitrofos" compost. Soil used in the experiment has characteristics as the following: $\mathrm{pH}$ of 5.26, C-organic of $0.29 \%$, Nitrogen of $0.04 \%$, P-available of $0.85 \mathrm{ppm}$, and $\mathrm{K}$ of $0.78 \mathrm{me} .100 \mathrm{~g}-1$. The soil was categorized as clay texture with a composition of sand of $26.71 \%$, dust of $21.67 \%$, clay of $51.62 \%$. Compost is made from cow dung, chicken manure, coconut husk powder, rice husk charcoal, MSG waste sludge, and oil palm empty fruit bunches (EFB) waste of a mushroom (Volvariella volvacea) growth medium [32]. The compost is characterized by a $\mathrm{C}-\mathrm{N}$ ratio of 12.75 , organic- $\mathrm{C}$ of $16.10 \%, \mathrm{~N}$ of $1.26 \%$, $\mathrm{P}$ of $3.02 \%$, and $\mathrm{K}$ of $0.41 \%$ [31].

Red lettuce seeds were sown first for 21 days in small pots placed on a seed tray. After that the seedlings were transplanted to growing pots, placed in a plastic house, and maintained until harvest. The plants were watered 1-2 times to maintain the moisture content of the growing medium at the field capacity level which was monitored by weighting. Plant parameters observed included height, stem diameter, number of leaves, canopy area, shoots fresh weight, dry weight, ash content, root length, water consumption, and water productivity.

The experiment used a completely randomized design (CRD) coupled with factorial arrangement, two factors and three replicates. The first factor was media size (S) which consisted of 3 levels namely: $1 \mathrm{~kg}$ (U1), 3kg (U2), and 5kg (U3). The second factor was the dose of compost (D) which consisted of 4 levels namely: 0\% (D0), 10\% (D1), 30\% (D2), 50\% (D3) based on the total weight of the media (soil + compost). Data were analyzed by using analysis of variance (ANOVA) and continued by using the least significant difference test (LSD) at a 95\% confidence interval 


\section{Results and discussion}

\subsection{Plant Growth Parameters}

\subsubsection{Plant height}

Analysis of variance showed that the effect of the treatment combination (growth medium size and compost dose) on plant height was significant at $\alpha=0.05$, and the interaction was significant too. The result of the treatment combination is presented in Table 1. Data of plant height ranged from $11.33 \mathrm{~cm}$ to $25.58 \mathrm{~cm}$. Regardless of the significances, the trends of plant height following the compost dose levels were slightly varying among the medium size levels. The trends of plant height at $1 \mathrm{~kg}$ and $3 \mathrm{~kg}$ medium size levels were alike, increasing from the lowest plant height at $0 \mathrm{~kg}$ compost dose level (D0), peaking at 10\% compost dose level (D1), then declining at the following compost dose levels (D2 and D3). At $5 \mathrm{~kg}$ medium size level (S3), the trend was consistently increasing from the lowest plant height at 0kg compost dose level (D0) to the highest plant height at 50\% compost dose level (D3) with little bumpy at 10\% compost dose level. The different trends could be an indication that plant growth had been depressed at smaller pots of media (S1 and S2) so increasing compost dose to higher levels did not increase that plant height. On the other hand, increasing compost dose was followed by increasing plant height when medium size (S3) and compost or organic fertilizer were not limited. Based on the LSD test; however, the best treatment combinations between medium size and compost dose were S1D1, S2D1, S2D2, and S3D3 with plant height of $28.17 \mathrm{~cm}, 30.17 \mathrm{~cm}, 27.67 \mathrm{~cm}$, and $32,50 \mathrm{~cm}$ respectively. That data of plant height was comparable to those reported by Masarirambi, et al. [33], when red lettuce was fertilized by using cattle manure and chicken manure.

Table 1 Effect of medium sizes and compost doses on plant height (cm)

\begin{tabular}{|c|c|c|c|c|c|c|c|c|c|}
\hline \multirow{3}{*}{$\begin{array}{l}\text { Medium Size (kg) } \\
1\left(\mathrm{~S}_{1}\right) \\
\end{array}$} & \multicolumn{8}{|c|}{ Compost Doses (\%) } & \multirow{3}{*}{$\begin{array}{l}\text { Average } \\
19.83 \\
\end{array}$} \\
\hline & \multicolumn{2}{|l|}{$0\left(\mathrm{D}_{0}\right)$} & \multicolumn{2}{|c|}{$10\left(\mathrm{D}_{1}\right)$} & \multicolumn{2}{|c|}{$30\left(\mathrm{D}_{2}\right)$} & \multicolumn{2}{|c|}{$50\left(D_{3}\right)$} & \\
\hline & 11.33 & $\mathrm{cB}$ & 28.17 & a A & 21.67 & $\mathrm{~b} \mathrm{~A}$ & 18.17 & b B & \\
\hline $3\left(\mathrm{~S}_{2}\right)$ & 16.17 & $\mathrm{~b} \mathrm{AB}$ & 30.17 & a A & 27.67 & a A & 21.17 & b B & 23.79 \\
\hline $5\left(S_{3}\right)$ & 19.83 & $\mathrm{cA}$ & 25.50 & bc A & 24.50 & $\mathrm{bcA}$ & 32.50 & $\mathrm{aA}$ & 25.58 \\
\hline Average & 15.78 & & 27.94 & & 24.61 & & 23.94 & & $(+)$ \\
\hline
\end{tabular}

*) Means with the same letters were not significantly different according to the LSD test $\alpha=0.05$. Lower cases were read horizontally, while upper cases were read vertically. The $(+)$ sign indicated that interaction was significant.

\subsubsection{Stem diameter}

Analysis of variance showed that the effects of medium size and compost dose level on stem diameter was significant at $\alpha=0.05$ and the interaction was significant as well. The result of the treatment combination is presented in Table 2 .

Table 2 Effect of medium sizes and compost doses on stem diameter (mm)

\begin{tabular}{|c|c|c|c|c|c|c|c|c|c|}
\hline \multirow{3}{*}{$\begin{array}{l}\text { Medium Size (kg) } \\
1\left(\mathrm{~S}_{1}\right)\end{array}$} & \multicolumn{8}{|c|}{ Compost Doses (\%) } & \multirow{3}{*}{$\begin{array}{l}\text { Average } \\
6.90\end{array}$} \\
\hline & \multicolumn{2}{|c|}{$0\left(\mathrm{D}_{0}\right)$} & \multicolumn{2}{|c|}{$10\left(\mathrm{D}_{1}\right)$} & \multicolumn{2}{|c|}{$30\left(D_{2}\right)$} & \multicolumn{2}{|c|}{$50\left(D_{3}\right)$} & \\
\hline & 5.0 & $\mathrm{~b} A$ & 7.1 & $\mathrm{aC}$ & 7.5 & a A & 5.6 & $\mathrm{bC}$ & \\
\hline $3\left(\mathrm{~S}_{2}\right)$ & 5.1 & $\mathrm{cA}$ & 8.5 & $\mathrm{a} A \mathrm{~B}$ & 8.0 & $\mathrm{ab} A$ & 7.7 & $\mathrm{~b}$ B & 7.33 \\
\hline $5\left(S_{3}\right)$ & 5.0 & $\mathrm{cA}$ & 7.6 & $\mathrm{~b} B \mathrm{BC}$ & 8.0 & ab A & 9.0 & a A & 7.40 \\
\hline Average & 5.82 & & 7.74 & & 7.82 & & 7.44 & & $(+)$ \\
\hline
\end{tabular}

*) Means with the same letters were not significantly different according to the LSD test $\alpha=0.05$. Lower cases were read horizontally, while upper cases were read vertically. The $(+)$ sign indicated that interaction was significant.

Stem diameter ranged from $5.0 \mathrm{~mm}$ to $9.0 \mathrm{~mm}$. The trends of the stem diameter were just similar to the plant height trends. At the levels of $1 \mathrm{~kg}$ medium size (S1), the trend was peaking at S1D2, while at 3kg medium size (S2) the trend was peaking at S2D1. At the level of $5 \mathrm{~kg}$ medium size (S3), the stem diameter was increasing from the lowest of $5.0 \mathrm{~mm}$ at $0 \%$ compost dose level (D0) to the highest of $9.0 \mathrm{~mm}$ at compost dose level (D3). So, as happened with plant height, the stem diameter parameter corroborated that plant had been depressed at smaller media (S1 and S2) rather than at bigger medium size (S3). At the smaller media (S1 and S2), increasing the compost dose was not followed by the 
increasing plant diameter. At higher medium size (S3), stem diameter was increasing with the compost dose. However, the LSD test showed that the best treatment combinations were S2D1, S2D2, S3D2, and S3D3 with stem diameters of $8.5 \mathrm{~mm}, 8.0 \mathrm{~mm}, 8.0 \mathrm{~mm}$, and $9.0 \mathrm{~mm}$ respectively. These best stem diameters were relatively smaller than those of green lettuce Lactuca sativa L. 'Vanity', which ranged from $9.7 \mathrm{~mm}$ to $17.5 \mathrm{~mm}$, as reported by Reis et al. [34].

\subsubsection{Number of leaves}

Analysis of variance showed that the effect of medium size and compost dose level on the number of leaves was significant at $\alpha=0.05$ but the interaction was not significant. The result of the treatment combination is presented in Table 3. On average, the number of leaves at $1 \mathrm{~kg}$ medium size (S1) were significantly fewer than those at $3 \mathrm{~kg}$ and $5 \mathrm{~kg}$ medium sizes (S2 and S3). The number of leaves at $0 \%$ compost dose (D0) were also significantly fewer than those at higher levels of compost doses (D1, D2, D3). Regardless of the significances, trends in the number of leaves were just similar to the trends of plant height and stem diameter. At $1 \mathrm{~kg}$ and $3 \mathrm{~kg}$ medium sizes (S1 and S2) the number of leaves were peaking at $10 \%$ compost dose (D1), while at $5 \mathrm{~kg}$ medium size (S3) the number of leaves continued increasing from D0 to D3. This fact verified that plant had been depressed already at $1 \mathrm{~kg}$ and $3 \mathrm{~kg}$ medium sizes. However, the number of leaves at $3 \mathrm{~kg}$ medium size (S2) was not significantly different from that at $5 \mathrm{~kg}$ medium size (S3) making best treatment combinations fell in S2D1, S2D2, S2D3, S3D1, S3D2, S3D3 with values of 16.0, 15.0, 14.7, 13.7, 14.3, 17.7 plant1 respectively. These best numbers of leaves were comparable to those (9-16 plant-1) of red lettuce reported by Masarirambi et al. [33].

Table 3 Effect of medium sizes and compost doses on number of leaves (plant ${ }^{-1}$ )

\begin{tabular}{|c|c|c|c|c|c|c|c|c|c|c|}
\hline \multirow{3}{*}{$\begin{array}{l}\text { Medium Size (kg) } \\
1\left(\mathrm{~S}_{1}\right) \\
\end{array}$} & \multicolumn{8}{|c|}{ Compost Doses (\%) } & \multirow{2}{*}{\multicolumn{2}{|c|}{ Average }} \\
\hline & \multicolumn{2}{|c|}{$0\left(\mathrm{D}_{0}\right)$} & \multicolumn{2}{|c|}{$10\left(D_{1}\right)$} & \multicolumn{2}{|c|}{$30\left(D_{2}\right)$} & \multicolumn{2}{|c|}{$50\left(\mathrm{D}_{3}\right)$} & & \\
\hline & 8.7 & & 14.0 & & 13.3 & & 12.0 & & 12.0 & B \\
\hline $3\left(\mathrm{~S}_{2}\right)$ & 10.3 & & 16.0 & & 15.0 & & 14.7 & & 14.0 & A \\
\hline $5\left(S_{3}\right)$ & 11.3 & & 13.7 & & 14.3 & & 17.7 & & 14.3 & $\mathrm{~A}$ \\
\hline Average & 10.1 & $\mathrm{~b}$ & 14.6 & a & 14.2 & a & 14.8 & a & $(-)$ & \\
\hline
\end{tabular}

*) Means with the same letters were not significantly different according to the LSD test $\alpha=0.05$. Lower cases were read horizontally, while upper cases were read vertically. The (-) sign indicated that interaction was not significant.

\subsubsection{Canopy area}

Analysis of variance showed that the effect of medium size and compost dose level on canopy area was significant at $\alpha$ $=0.05$ but the interaction was not significant. The result of the LSD test is presented in Table 4 . The canopy area ranged from $66.08 \mathrm{~cm} 2$ to $479.53 \mathrm{~cm} 2$. On average, canopy area at $1 \mathrm{~kg}$ medium size (S1) was less than those in $3 \mathrm{~kg}$ and $5 \mathrm{~kg}$ medium sizes (S2 and S3); whereas at 0\% compost dose (D0) plant had less canopy area than those at higher levels of compost doses (D1, D2, D3). The trends of canopy area; however, just the same as the previous parameters (plant height, stem diameter, and number of leaves) peaking at D1 for $1 \mathrm{~kg}$ and $3 \mathrm{~kg}$ medium sizes (S1 and S2) and increasing continuously for $5 \mathrm{~kg}$ medium size. The trends of canopy area also agreed with the previous parameters (plant height, stem diameter, number of leaves). Results of LSD test exhibited best treatment combinations based on canopy area included S2D1, S2D2, S2D3, S3D1, S3D2, S3D3 with values of 530.04, 408.41, 357.91, 357.85, 418.00, 479.53 $\mathrm{cm}^{2}$ respectively.

Table 4 Effect of medium sizes and compost doses on canopy area $\left(\mathrm{cm}^{2}\right)$

\begin{tabular}{|c|c|c|c|c|c|c|c|c|c|c|}
\hline \multirow{3}{*}{$\begin{array}{l}\text { Medium Size (kg) } \\
1\left(\mathrm{~S}_{1}\right) \\
\end{array}$} & \multicolumn{8}{|c|}{ Compost Doses (\%) } & \multirow{2}{*}{\multicolumn{2}{|c|}{ Average }} \\
\hline & \multicolumn{2}{|l|}{$0\left(\mathrm{D}_{0}\right)$} & \multicolumn{2}{|l|}{$10\left(\mathrm{D}_{1}\right)$} & \multicolumn{2}{|l|}{$30\left(D_{2}\right)$} & \multicolumn{2}{|l|}{$50\left(D_{3}\right)$} & & \\
\hline & 66.08 & & 311.72 & & 268.93 & & 165.60 & & 203.08 & B \\
\hline $3\left(S_{2}\right)$ & 91.83 & & 530.04 & & 408.41 & & 357.91 & & 347.05 & $\mathrm{~A}$ \\
\hline $5\left(S_{3}\right)$ & 118.52 & & 357.85 & & 418.00 & & 479.53 & & 343.47 & $\mathrm{~A}$ \\
\hline Average & 92.14 & $\mathrm{~b}$ & 399.87 & $\mathrm{a}$ & 365.11 & $\mathrm{a}$ & 334.35 & $\mathrm{a}$ & $(-)$ & \\
\hline
\end{tabular}

*) Means with the same letters were not significantly different according to the LSD test $\alpha=0.05$. Lower cases were read horizontally, while upper cases were read vertically. The (-) sign indicated that interaction was not significant. 


\subsection{Harvest Parameters}

\subsubsection{Shoot fresh weight}

Analysis of variance showed that the effect of the medium size and compost dose on shoot fresh weight was significant, and the interaction effect was significant as well. The result of the LSD test was presented in Table 5. The data showed that shoot fresh weights ranged from $4,2 \mathrm{~g}$ to $90 \mathrm{~g}$. The trends following the compost dose levels at the levels of $1 \mathrm{~kg}$ (S1) and $3 \mathrm{~kg}$ (S2) medium sizes were alike, initially increasing from 0\% compost dose (D0), peaking at the $10 \%$ compost (D1) then declining at the following compost dose levels (D2, D3). At the level of $5 \mathrm{~kg}$ medium size (S3), the trend was consistently increasing from $0 \%$ compost dose level (D0) to 50\% compost dose level (D3). These patterns were the same as the trends of previous parameters (plant height, stem diameter, number of leaves, and canopy area), strongly verified that plant was depressed at medium sizes of $1 \mathrm{~kg}$ and $3 \mathrm{~kg}$ (D1 and D2). The LSD test; however, showed that the best three treatment combinations were S2D1, S2D2, and S3D3 with values of $75.3 \mathrm{~cm}, 65.7 \mathrm{~cm}$, and $90.0 \mathrm{~cm}$ respectively. These best shoot the fresh weights were lower than fresh weight of hydroponic Lollo Rosa (187.25 g plant-1) reported by Drăghici et al. [35], but still better than those of green lettuce (33.13-45.4 g plant-1) reported by Peiris and Weerakkody [36].

Table 5 Effect of medium sizes and compost doses on shoot fresh weight $(\mathrm{g})$

\begin{tabular}{|c|c|c|c|c|c|c|c|c|c|}
\hline \multirow{2}{*}{ Medium Size (kg) } & \multicolumn{8}{|c|}{ Compost Doses (\%) } & \multirow{3}{*}{ Average } \\
\hline & \multicolumn{2}{|c|}{$0\left(\mathrm{D}_{0}\right)$} & \multicolumn{2}{|c|}{$10\left(\mathrm{D}_{1}\right)$} & \multicolumn{2}{|c|}{$30\left(\mathrm{D}_{2}\right)$} & \multicolumn{2}{|c|}{$50\left(D_{3}\right)$} & \\
\hline \multicolumn{9}{|c|}{ Shoot fresh weight (g) } & \\
\hline $1\left(\mathrm{~S}_{1}\right)$ & 4.2 & $\mathrm{bA}$ & 51.0 & a A & 37.0 & $\mathrm{aC}$ & 24.1 & a C & 29.1 \\
\hline $3\left(\mathrm{~S}_{2}\right)$ & 11.9 & $\mathrm{bA}$ & 75.3 & $\mathrm{aA}$ & 65.7 & $\mathrm{a} A \mathrm{~B}$ & 52.3 & a BC & 51.3 \\
\hline $5\left(\mathrm{~S}_{3}\right)$ & 17.0 & $\mathrm{cA}$ & 55.3 & $\mathrm{~b} \mathrm{~A}$ & 58.7 & $\mathrm{~b} B C$ & 90.0 & a A & 55.3 \\
\hline Average & 11.0 & & 60.6 & & 53.8 & & 55.5 & & $(+)$ \\
\hline
\end{tabular}

*) Means with the same letters were not significantly different according to the LSD test $\alpha=0.05$. Lowercase was read horizontally, while uppercase was read vertically. The $(+)$ sign indicated that interaction was significant.

\subsubsection{Shoot dry weight}

Analysis of variance showed that the effect of the medium size and compost dose on shoot dry weight was significant, but the interaction effect was not significant. The result of the LSD test was presented in Table 6. Shoot dry weight Data ranged from $0.38 \mathrm{~g}$ to $13,67 \mathrm{~g}$. Even-though the interaction effect on shoot dry weight was not significant, the trends were more or less similar to those of previous parameters (plant height, stem diameter, number of leaves, canopy area, and shoot fresh weight), exhibiting that plant was depressed at $1 \mathrm{~kg}$ and $3 \mathrm{~kg}$ medium sizes, while at $5 \mathrm{~kg}$ medium size the plant did not show an indication of un normal growth. The best treatment combinations were the same as shown by the number of leaves and canopy area parameters. The best shoot dry weights ranged from 11.00 to $13.67 \mathrm{~g}$ which were still higher than those (3.77g to $9.21 \mathrm{~g}$ ) of red lettuce 'Veneza Roxa' reported by Masarirambi et.al [37].

Table 6 Effect of medium sizes and compost doses on shoot dry weight $(\mathrm{g})$

\begin{tabular}{|c|c|c|c|c|c|c|c|c|c|c|}
\hline \multirow{3}{*}{$\begin{array}{l}\text { Medium Size (kg) } \\
1\left(\mathrm{~S}_{1}\right) \\
\end{array}$} & \multicolumn{8}{|c|}{ Compost Doses (\%) } & \multirow{2}{*}{\multicolumn{2}{|c|}{ Average }} \\
\hline & \multicolumn{2}{|c|}{$0\left(\mathrm{D}_{0}\right)$} & \multicolumn{2}{|c|}{$10\left(\mathrm{D}_{1}\right)$} & \multicolumn{2}{|c|}{$30\left(D_{2}\right)$} & \multicolumn{2}{|c|}{$50\left(\mathrm{D}_{3}\right)$} & & \\
\hline & 0.38 & & 10.67 & & 10.33 & & 7.13 & & 7.13 & $\mathrm{~B}$ \\
\hline $3\left(\mathrm{~S}_{2}\right)$ & 0.81 & & 12.00 & & 12.33 & & 11.00 & & 9.04 & A \\
\hline $5\left(S_{3}\right)$ & 1.13 & & 11.33 & & 12.00 & & 13.67 & & 9.53 & A \\
\hline Average & 0.77 & $\mathrm{~b}$ & 11.33 & a & 11.56 & a & 10.60 & a & $(-)$ & \\
\hline
\end{tabular}

*) Means with the same letters were not significantly different according to the LSD test $\alpha=0.05$. Lowercase was read horizontally, while uppercase was read vertically. The (-) sign indicated that interaction was not significant.

\subsubsection{Root fresh weight}

Analysis of variance showed that the effect of the medium size and compost dose on root fresh weight was significant, and the interaction effect was significant too. The result of LSD test was presented on Table 7. Data of root fresh weight ranged from $4.42 \mathrm{~g}$ to $15.25 \mathrm{~g}$ (S3D3). The trend of the root fresh weight was also quite similar to those of previous parameters (plant height, stem diameter, number of leaves, canopy area, shoot fresh weight, and shoot dry weight). 
Hence, the trend of root fresh weight also supported the conclusive interpretation that the plant was depressed at $1 \mathrm{~kg}$ and 3kg medium doses (D1 and D2), but was not in 5kg medium size (S3). The best treatment combinations were S2D1, S2D3, and S3D3 with values of $14.64 \mathrm{~g}, 12.00 \mathrm{~g}$, and 15,25g respectively.

Table 7 Effect of medium sizes and compost doses on root fresh weight (g)

\begin{tabular}{|c|c|c|c|c|c|c|c|c|c|}
\hline \multirow{3}{*}{$\begin{array}{l}\text { Medium Size (kg) } \\
1\left(\mathrm{~S}_{1}\right)\end{array}$} & \multicolumn{8}{|c|}{ Compost Doses (\%) } & \multirow{2}{*}{ Average } \\
\hline & \multicolumn{2}{|c|}{$0\left(D_{0}\right)$} & \multicolumn{2}{|c|}{$10\left(D_{1}\right)$} & \multicolumn{2}{|c|}{$30\left(D_{2}\right)$} & \multicolumn{2}{|c|}{$50\left(D_{3}\right)$} & \\
\hline & 4.42 & с B & 11.61 & $\mathrm{ab} B \mathrm{BC}$ & 8.58 & $\mathrm{bA}$ & 8.77 & b B & 8.34 \\
\hline $3\left(\mathrm{~S}_{2}\right)$ & 6.79 & $\mathrm{cAB}$ & 14.64 & $\mathrm{ab} \mathrm{AB}$ & 11.43 & $\mathrm{bA}$ & 12.00 & ab $A B$ & 10.38 \\
\hline $5\left(S_{3}\right)$ & 8.37 & $\mathrm{~b} \mathrm{~A}$ & 10.11 & $\mathrm{bc}$ & 11.73 & $\mathrm{bA}$ & 15.25 & a $\mathrm{A}$ & 11.37 \\
\hline Average & 6.53 & & 12.12 & & 10.58 & & 12.01 & & $(+)$ \\
\hline
\end{tabular}

*) Means with the same letters were not significantly different according to the LSD test $\alpha=0.05$. Lowercase was read horizontally, while uppercase was read vertically. The $(+)$ sign indicated that interaction was significant.

\subsubsection{Root length}

Analysis of variance showed that growth medium size was the only significant treatment on the root length parameter. The result of the LSD test was presented in Table 8. Data of root length ranged from $10.60 \mathrm{~cm}$ to $16.20 \mathrm{~cm}$. The trend of root length did not follow the compost dose levels, but the data showed that root length at the $1 \mathrm{~kg}$ and $3 \mathrm{k}$ medium sizes (D1 and D2) was significantly shorter than that at $5 \mathrm{~kg}$ medium size, indicating that root development was restricted at D1 and D2. Hence, root length data also discovered that plant had been depressed at $1 \mathrm{~kg}$ and $3 \mathrm{~kg}$ medium sizes as shown by all of the previous parameters.

Table 8 Effect of medium sizes and compost doses on root length $(\mathrm{cm})$

\begin{tabular}{|c|c|c|c|c|c|c|}
\hline \multirow{3}{*}{$\begin{array}{l}\text { Medium Size (kg) } \\
1(\mathrm{~S} 1)\end{array}$} & \multicolumn{4}{|c|}{ Compost Doses (\%) } & \multirow{2}{*}{\multicolumn{2}{|c|}{ Average }} \\
\hline & \multicolumn{2}{|l|}{0 (D0) } & \multicolumn{2}{|c|}{30 (D2) } & & \\
\hline & 10.67 & 10.60 & 13.63 & 12.23 & 11.78 & B \\
\hline $3(\mathrm{~S} 2)$ & 12.80 & 11.77 & 13.13 & 12.83 & 12.63 & B \\
\hline $5(\mathrm{~S} 3)$ & 15.10 & 14.23 & 16.20 & 13.20 & 14.68 & A \\
\hline Average & 12.86 & 12.20 & 14.32 & 12.76 & $(-)$ & \\
\hline
\end{tabular}

*) Means with the same letters were not significantly different according to the LSD test $\alpha=0.05$. Lowercase was read horizontally, while uppercase was read vertically. The (-) sign indicated that interaction was not significant.

\subsection{Water Consumption and Water Productivity}

\subsubsection{Water consumption}

Water consumption or water use is mainly used by plants for evapotranspiration. Water use is a very important production factor because this factor can determine the feasibility of farming, especially horticulture. Farmers who rely on rainwater have discontinuous horticultural businesses. Analysis of variance showed that the effect of the medium size and compost dose on water use was significant, and the interaction effect was significant too. The result of LSD test was presented in Table 9. Water consumption ranged from $2323.3 \mathrm{~mL}-7130.0 \mathrm{~mL}$. As a healthy plant consumes more water because of a faster evaporation rate, the amount of water consumption could be used as indicator of the degree of plant growth. The trend of water consumption was just the same as shown by other previous parameters. At $1 \mathrm{~kg}$ and $3 \mathrm{~kg}$ medium sizes (S1 and S2) water consumption was peaking at 10\% compost dose (D1), while at 5kg medium size the continually increasing water consumption was visible. The LDS test also showed that S3D3 was the single best treatment combination with a value of $7130.0 \mathrm{~mL}$. 
Table 9 Effect of medium size and compost dose on water consumption (mL)

\begin{tabular}{|c|c|c|c|c|c|c|c|c|c|}
\hline \multirow{3}{*}{$\begin{array}{l}\text { Medium Size (kg) } \\
1(\mathrm{~S} 1)\end{array}$} & \multicolumn{8}{|c|}{ Compost Doses (\%) } & \multirow{3}{*}{$\begin{array}{l}\text { Average } \\
2884.2\end{array}$} \\
\hline & \multicolumn{2}{|l|}{$0\left(\mathrm{D}_{0}\right)$} & \multicolumn{2}{|l|}{$10\left(D_{1}\right)$} & \multicolumn{2}{|l|}{$30\left(D_{2}\right)$} & \multicolumn{2}{|l|}{$50\left(D_{3}\right)$} & \\
\hline & 2323.3 & $\mathrm{cC}$ & 3431.7 & a A & 3140.0 & $\mathrm{ab} C$ & 2641.7 & $\mathrm{bcC}$ & \\
\hline $3(\mathrm{~S} 2)$ & 4410.0 & b B & 5615.0 & a A & 5401.7 & a $\mathrm{B}$ & 5456.7 & a $\mathrm{B}$ & 5220.9 \\
\hline $5(\mathrm{~S} 3)$ & 5283.3 & c A & 5278.3 & c A & 6123.3 & b A & 7130.0 & a A & 5953.7 \\
\hline Average & 4005.5 & & 4775.0 & & 4888.3 & & 5076.1 & & $(+)$ \\
\hline
\end{tabular}

*) Means with the same letters were not significantly different according to the LSD test $\alpha=0.05$. Lowercase was read horizontally, while uppercase was read vertically. The $(+)$ sign indicated that interaction was significant.

\subsubsection{Water productivity}

Some people call it interchangeably between water use efficiency and water productivity. But the term of water productivity simply refers to yield over water consumption. This parameter is an important criterion in determining efficient and sustainable cultivation. Analysis of variance showed that the compost dosage treatment was the only significant treatment on water productivity. The result of the LSD test is presented in Table 10. The water productivity ranged from $1.77 \mathrm{~g} . \mathrm{L}^{-1}$ to $12.79 \mathrm{~g} . \mathrm{L}^{-1}$, but the $\mathrm{LSD}$ test showed that the trend of water productivity was peaking at $10 \%$ compost dose (D1), although not significantly different from D2, at all levels of medium sizes. So, the best treatment was $10 \%$ compost dose (D1) at every level of medium sizes.

Table 10 Effect of medium size and compost dose on water productivity (g.L-1).

\begin{tabular}{|c|c|c|c|c|c|c|c|c|c|}
\hline \multirow{3}{*}{$\begin{array}{l}\text { Medium Size (kg) } \\
1(\mathrm{~S} 1) \\
\end{array}$} & \multicolumn{8}{|c|}{ Compost Doses (\%) } & \multirow{3}{*}{$\begin{array}{l}\text { Average } \\
9.32\end{array}$} \\
\hline & \multicolumn{2}{|l|}{$0\left(\mathrm{D}_{0}\right)$} & \multicolumn{2}{|c|}{$10\left(D_{1}\right)$} & \multicolumn{2}{|c|}{$30\left(D_{2}\right)$} & \multicolumn{2}{|c|}{$50\left(D_{3}\right)$} & \\
\hline & 1.77 & & 14.83 & & 11.87 & & 8.80 & & \\
\hline $3(\mathrm{~s} 2)$ & 2.73 & & 13.10 & & 12.17 & & 9.47 & & 9.37 \\
\hline 5 (S3) & 3.23 & & 10.43 & & 9.47 & & 8.37 & & 7.88 \\
\hline Average & 2.58 & c & 12.79 & a & 11.17 & $\mathrm{ab}$ & 8.88 & $\mathrm{~b}$ & $(-)$ \\
\hline
\end{tabular}

*) Means with the same letters were not significantly different according to the LSD test $\alpha=0.05$. Lowercase was read horizontally, while uppercase was read vertically. The (-) sign indicated that interaction was not significant.

\subsection{Determination of optimum treatment}

All best treatment combinations of all parameters discussed above are summarized in Table 11 . The objective parameter is the shoot fresh weight or yield because this is the consumable and marketable part of the plans, while the others are indicator or predictive parameters. Hence, the optimum treatment combination was determined on the basis of optimum fresh weight or yield. The optimum treatment referred to the same productivity while using smaller medium sizes and compost dose levels as compared to the production at larger medium sizes and higher compost dose levels.

As mentioned before, the plant growth was depressed at $1 \mathrm{~kg}$ and $3 \mathrm{~kg}$ medium sizes (S1 and S2) and growing well at 5kg medium size based on the trends of all parameters except the trend of water productivity. In Table 11 we can see that even S2 showed depressed plant growths, but it could give statistically the same growth as S3 gave for the most parameters. Based on shoot fresh weight, S2D1 performed as the most optimum treatment because the yield was not statistically different from that produced by S2D2 and S3D3. Increasing the medium size and compost doses to S2D2, S3D3 did not statistically improve the yield. Referring to Table 5, S2D1 (3kg medium size and 10\% compost dose level) produced $75.3 \mathrm{~g}$ yield per plant. Other harvest parameters (shoot dry weight and root fresh weight) except for root length, agreed with shoot fresh weight parameter, witnessing that S2D1 was the most optimum treatment. 
Table 11 Summary of best treatment combinations

\begin{tabular}{|l|l|l|}
\hline No & Parameters & Statistically Best Treatment Combinations \\
\hline 1 & Shoot Fresh Weight (yield) & S2D1, S2D2, S3D3 \\
\hline 2 & Plant height & S1D1, S2D1, S2D2, S3D3 \\
\hline 3 & Stem Diameter & S2D1, S2D2, S3D2, S3D3 \\
\hline 4 & Number of Leaves & S2D1, S2D2, S2D3, S3D1, S3D2, S3D3 \\
\hline 5 & Canopy Area & S2D1, S2D2, S2D3, S3D1, S3D2, S3D3 \\
\hline 6 & Shoot Dry Weight & S2D1, S2D2, S2D3, S3D1, S3D2, S3D3 \\
\hline 7 & Root Fresh Weight & S2D1, S2D3, S3D3 \\
\hline 8 & Root Length & S3D0, S3D1, S3D2, S3D3 \\
\hline 9 & Water Consumption & S3D3 \\
\hline 10 & Water Productivity & S1D1, S1D2, S2D1, S2D2, S3D1, S3D2 \\
\hline
\end{tabular}

Plant height parameter showed that S1D1 came up to be one of the best treatments. It could be a bolting effect, a stem elongation when the flowering stage is initiated. Bolting is commonly triggered by high temperature (owing that the research location was characterized by high atmospheric temperature) and unfavorable growth medium conditions $[37$.

The fact that root length was shorter at S1 and S2 and longer at S3 (at all levels of compost doses) strongly verified that plant had been depressed at S1 and S2. When roots were restricted by a container the plant growths were suboptimal because the roots compete for essential resources [19]. The depressed growth was also shown by all plant growth parameters (plant height, stem diameter, number of leaves, canopy area). One important point to note here was that although in the restricting condition of media (S2), the plant could still produce an optimum yield as in S2D1 elaborated above.

The highest water consumption shown by S3D3, indicating that larger medium size consumed more water (higher evapotranspiration rate) due to wider medium surface area and better plant growth. Data showed that the plant at S3D3 consumed $7130.0 \mathrm{~mL}$ water and gave a $90.0 \mathrm{~g}$ yield although this yield was not the most optimum. The highest water productivity, on the other hand, was performed by D1 and D2 regardless of medium sizes. The highest water productivity meant the most efficient water usage. The treatments of S1D1 and S1D2 could be a crucial option especially for locations with scarce water. If the availability of water resources is not a major problem, the choice is normally based on the optimum yield.

\section{Conclusion}

Results of this research study revealed that red rapid lettuce was depressed at $1 \mathrm{~kg}$ and $3 \mathrm{~kg}$ medium sizes and growing more freely at $5 \mathrm{~kg}$ medium size. Three best yields of $75.3 \mathrm{~g}, 65.7 \mathrm{~g}$ and $90.0 \mathrm{~g}$ per plant were performed by the treatment combinations of $3 \mathrm{~kg}$ medium size- $10 \%$ compost dose (S2D1), 3kg medium size-30\% compost dose (S2D2), and $5 \mathrm{~kg}$ medium size-50\% compost dose (S3D3). The treatment combination of S2D1; however, could be considered as the most optimum treatment combination since it used the least amount of medium and compost although the plant experienced in restricted growth.

\section{Compliance with ethical standards}

\section{Acknowledgments}

Great appreciation is extended to the Indonesian Ministry of Research, Technology and Higher Education for the funding of this research. 


\section{Disclosure of conflict of interest}

The authors declare no conflict of interest.

\section{Author's contributions}

Dermiyati, Jamalam Lumbanraja, and Sugeng Triyono are in the team work developing the organic compost named "Oganonitrofos". Dermiyati is primarily responsible for microbiological aspect, Jamalam Lumbanraja is responsible for chemical properties, and Sugeng Triyono is responsible for the application development and initiates this manuscript. Fadli Afrizki Surya Aditama contributed the research implementation, while Elhamida Rezkia contributed in the experimental design.

\section{References}

[1] Worthington V. Nutritional quality of organic versus conventional fruits, vegetables, and grains [Internet]. First published in: The journal of alternative and complementary medicine. 2001; 7(2): 161-173.

[2] Kyrylov Y, Thompson SR, Hranovska V, Krykunova V. The world trends of organic production and consumption. Manag Theory Stud Rural Bus Infrastruct Dev. 2018; 40(4): 514-30.

[3] Bostan I, Onofrei M, Gavriluță (Vatamanu) AF, Toderașcu C, Lazăr CM. An integrated approach to current trends in organic food in the EU. Foods. 2019 May; 8(5): 144-61.

[4] Faostat. Agriculture area certified organic. food and agriculture organization of the united nations statistic [Internet]. 2018 [cited 2020 Dec 5].

[5] Meena RP, Meena HP, Meena RS. Organic farming: concept and components. Pop Kheti. 2013; 1(4): 5-14.

[6] Caliskan S, Yetisir H, Karanlik S. Combined Use of Green Manure and Farmyard Manure Allows Better Nutrition of Organic Lettuce. Not Bot Horti Agrobot Cluj-Napoca. 2014 Jun 3; 42(1): 248-54.

[7] Sivaranjani S, Rakshit A. Organic farming in protecting water quality. In: Sarath Chandran C, Thomas S, Unni MR, editors. Organic Farming: New Advances Towards Sustainable Agricultural Systems [Internet]. Cham: Springer International Publishing. 2019; 1-9.

[8] Benbrook CM, Baker BP. Perspective on dietary risk assessment of pesticide residues in organic food. Sustainability. 2014; 6(6): 3552-70.

[9] Nuberg IK. Effect of shelter on temperate crops: a review to define research for Australian conditions. Agrofor Syst. 1998; 41(1): 3-34.

[10] Sharifi O, Sadati SA, Ghobadi FR, Sadati SA, Mohamadi Y, Del PTT. Barriers to conversion to organic farming: a case study in Babol County in Iran. Afr J Agric Res. 2010; 5(16): 2260-7.

[11] Kumar S, Saravaiya SN. Organic farming in vegetable crops under protected culture in urban and peri-urban centers - An Approach Paper. The Allahabad Farmer Vol. LXXII, July- 2016 No. 1: 113-125.

[12] Bruggen AH van, Gamliel A, Finckh MR. Plant disease management in organic farming systems. Pest Manag Sci. 2016; 72(1): 30-44.

[13] Simonne E, Hochmuth R, Breman J, Lamont W, Treadwell D, Gazula A. Drip-irrigation systems for small conventional vegetable farms and organic vegetable farms. IFAS Extension, University of Florida. 2018; 1-24.

[14] Owusu V, Anifori MO. Consumer Willingness to Pay a Premium for Organic Fruit and Vegetable in Ghana. International Food and Agribusiness Management Review. 2013; 16(1): 67-86.

[15] Wang L, Huo X. Willingness-to-pay price premiums for certified fruits -A case of fresh apples in China. Food Control. 2016; 64(1): 240-6.

[16] Rani S, Shah H, Nusrat H, Khan MA. Consumers' preferences and willingness to pay for organic vegetables in Islamabad, Pakistan. Sarhad J Agric [Internet]. 2018 [cited 2020 Dec 5]; 34(3).

[17] Reddy V, Ramappa K. An economic analysis of organic farming systems in Gadag District of Karnataka (india). Int J Dev Emerg Econ. 2014; 1(1): 1-10.

[18] Carey T, Dremsa R, Bandli R, Smith J. Growing vegetables in pots. [Internet]. Kansas State University Agricultural Experiment Station and Cooperative Extension Service. 2009 [cited 2020 Oct 25]. 
[19] Masabni JG. Vegetable gardening in containers. [Internet]. Agrilife Extension Texas A\&M system; 2020 [cited 2020 Oct 25].

[20] NeSmith DS, Duval JR. The effect of container size. horttechnology. 1998; 8(4).

[21] Serafini M, Bugianesi R, Salucci M, Azzini E, Raguzzini A, Maiani G. Effect of acute ingestion of fresh and stored lettuce (Lactuca sativa) on plasma total antioxidant capacity and antioxidant levels in human subjects. $\mathrm{Br} \mathrm{J} \mathrm{Nutr}$. 2002; 88(6): 615-23.

[22] Llorach R, Martínez-Sánchez A, Tomás-Barberán FA, Gil MI, Ferreres F. Characterisation of polyphenols and antioxidant properties of five lettuce varieties and escarole. Food Chem. 2008; 108(3): 1028-38.

[23] Heimler D, Vignolini P, Arfaioli P, Isolani L, Romani A. Conventional, organic and biodynamic farming: differences in polyphenol content and antioxidant activity of Batavia lettuce. J Sci Food Agric. 2012; 92(3): 551-6.

[24] Baslam M, Moralesa F, Garmendia I, Goicoechea N. Nutritional quality of outer and inner leaves of green and red pigmented lettuces (Lactuca sativa L.) consumed as salads. Sci Hortic. 2013; 151(1):103-111.

[25] Hipol RLB, Dionisio-Sese M. Impact of Light Variation on the Antioxidant Properties of Red Lettuce [Internet]. undefined. 2014 [cited 2020 Dec 5].

[26] Zapata-Vahos IC, Rojas-Rodas F, David D, Gutierrez-Monsalve JA, Castro-Restrepo D. Comparison of antioxidant contents of green and red leaf lettuce cultured in hydroponic systems under greenhouse, and conventional soil culture. Rev Fac Nac Agron Medellín. 2020; 73(1): 9077-88.

[27] Brito A, Areche C, Sepúlveda B, Kennelly EJ, Simirgiotis MJ. Anthocyanin characterization, total phenolic quantification and antioxidant features of some chilean edible berry extracts. Molecules. 2014; 19(8): 10936-55.

[28] Ako H, Baker A. Small-scale lettuce production with hydroponics or aquaponics. sustainable. Univ Hawaii [Internet]. 2009.

[29] Nugroho SG, Dermiyati, Lumbanraja J, Triyono S, Ismono H. Inoculation effect of N2-fixer and P-solubilizer into a mixture of fresh manure and phosphate rock formulated as Organonitrofos fertilizer on bacterial and fungal populations. J Trop SOILS. 19 Mar 2013; 18(1): 75-80.

[30] Dermiyati, Utomo SD, Hidayat KF, Lumbanraja J, Triyono S, Ismono H, et al. Effectiveness of organonitrofos plus fertilizer on sweet corn and soil chemical properties of ultisols. J Trop SOILS. 2016; 21(1): 9-17.

[31] Triyono S, Pujiono R, Zulkarnain I, Haryanto A, Dermiyati D, Lumbanraja J. The effects of empty fruit bunch treatments for straw mushroom substrate on physicochemical properties of a biofertilizer. J Tek Pertan Lampung. 2019; 8(2): 120-9.

[32] Triyono S, Haryanto A, Telaumbanua M, Dermiyati D, Lumbanraja J, To F. Cultivation of straw mushroom (Volvariella volvacea) on oil palm empty fruit bunch growth medium. Int J Recycl Org Waste Agric. 2019; 8(4): 381-392.

[33] Masarirambi MT, Dlamini P, Phiwokwakhe PK, Oseni TO. Effects of Chicken Manure on Growth, Yield and Quality of Lettuce (Lactuca sativa L.) "Taina" Under a Lath House in a Semi-Arid Sub-Tropical Environment. AmericanEurasian J. Agric. \& Environ. Sci. 2012; 12(3): 399-406.

[34] Reis M, Coelho L, Beltrão J, Domingos, Moura. Comparative effects of inorganic and organic compost fertilization on lettuce (Lactuca sativa). Int J Energy Environ. 2014; 8(1): 108-17.

[35] Draghici EM, Dobrin E, Jerca IO, Barbulescu IM, Jurcoane S, Lagunovschi-Luchian V. Organic fertilizer effect on Lettuce (Lactuca sativa L.) cultivated in nutrient film technology. Romanian Biotechnol Lett. 2016; 21(5): 1190513.

[36] Peiris U, Weerakkody P. Effect of Organic Based Liquid Fertilizers on Growth Performance of Leaf Lettuce (Lactuca Sativa L.). International Conference on Agricultural, Ecological and Medical Sciences (AEMS-2015) April 7-8, 2015 Phuket (Thailand).

[37] Masarirambi MT, Hlawe M, Oseni OT, Sibiya TE. Effects of organic fertilizers on growth, yield, quality and sensory evaluation of red lettuce (Lactuca sativa L.) 'Veneza Roxa'. Agric. Biol. J. N. Am. 2010; 1(6): 1319-1324. 